\title{
Behavior and Performance of Broiler Strains Reared under Semi-Intensive System with Shaded Areas
}

-Author(s)
Barbosa Filho JAD 1
Silva MAN²
Silva IJO'
Coelho AAD2
Savino VJM²
1 Dep. de Engenharia Rural - NUPEA/ESALQ/
USP
2 Dep. de Genética - NUPEA/ESALQ/USP

\section{Mail Address}

José Antonio Delfino Barbosa Filho Escola Superior de Agricultura Luiz de Queiroz Departamento de Engenharia Rural Núcleo de Pesquisa em Ambiência Av. Pádua Dias, 11 - Caixa Postal 09 13.418-900. Piracicaba, SP, Brazil Phone: +55 $193429-4217$ ext. 238 Fax: $\quad+55193422-6675$

E-mail: joseadbf@esalq.usp.br

\section{Keywords}

Adaptation, broiler, semi-intensive system, welfare.

\section{ABSTRACT}

The matter of animal welfare has led to studies in order to evaluate alternative rearing systems for livestock in order to improve well-being. The semi-intensive system is an alternative method of rearing broilers in which the birds are kept in a poultry house and have free access to a pasture area during the day. It is known that ambient conditions may directly affect the behavior of birds reared in the semi-intensive system. Therefore, this research evaluated the behavior of four broiler strains reared under a semi-intensive system with a shaded area (provided by a black plastic screen - 50\%) and the bioclimatic characteristics of this environment when compared with the non-shaded pasture. Thirty-five birds were reared in pens with $4.5 \mathrm{~m}^{2}$ and $35 \mathrm{~m}^{2}$ of pasture. Ambient variables were measured throughout the day to calculate the indexes of thermal comfort (BGHI and enthalpy). Data was analyzed in a $4 \times 2$ factorial (4 strains and 2 rearing environments) with 2 repetitions, in order to establish the rate of bird permanence in the pasture. There was an improvement in the ambient conditions of the shaded pasture in the hottest hours of the day (from 10:00 to 14:00 h), i.e., there was a reduction in the mean values of $\mathrm{BGHI}$ (approximately $26 \%$ ) and enthalpy $(36 \%)$. As a consequence, there was an increase in the rate of permanence in this environment if compared with the non-shaded pasture. Three out of four evaluated strains showed better adaptability to the semi-intensive rearing system.

\section{INTRODUCTION}

Among the available rearing systems for birds, the semi-intensive system consists in keeping the birds in an area with a shed and pasture, i.e., the birds are kept in a poultry house and have free access to a pasture area.

The system has been increasingly used in the last years, mainly due to aspects related to the greater concern with food quality by consumers. Besides, production costs might also be reduced, since the birds will have access to a pasture area and the costs with diets would be decreased (Silva \& Nakano, 1998; Silva, 2001).

The utilization of semi-intensive systems minimizes the effects of stressing factors and contributes to bird welfare. According to Sundrum (2001), animal health and well-being may be affected by increasing the area in which the animal is able to move. Once the birds stay longer in the pasture area, they have greater mobility and welfare will be improved. Therefore, productivity and profits might be improved in alternative poultry production if strains adapted to this system are used.

Environmental conditions are extremely important to bird rearing and affect bird behavior directly. Temperature, relative humidity and sun radiation are important indexes of environment quality to the animal 
Barbosa Filho JAD, Silva MAN, Silva IJO, Coelho AAD, Savino VJM
Behavior and Performance of Broiler Strains Reared under Semi-Intensive System with Shaded Areas
(Bockisch et al., 1999), since these factors may cause stress (Furlan et al., 1999; Silva, 2001).

The thermal ambient is represented by temperature, humidity and radiation, and affects birds directly, compromising the most important vital function, i.e., maintenance of the homeothermy. The combined effects of temperature, humidity and radiation might be quantified by the black globe and humidity index (BGHI). Teixeira (1983) reported that a BGHI value of 76 is the superior critical point to broiler chickens between 21 and 50 days of age, based on feed intake and weight gain. Nevertheless, BGHI values higher than 76 have been observed during the summer, which decreases the productive performance of birds and constitutes one of the most important problems in broiler rearing (Curtis, 1983).

In such situations, climatic limitations might be minimized as a result of adequate building projects together with rational feeding and management, as well as techniques of ambient thermal modifications (Curtis, 1983).

As long as possible, ambient conditions should thus be managed to prevent negative effects on the productive performance of birds, since they might affect metabolism and result in negative effects on meat production (Macari \& Furlan, 2001).

According to Craig \& Muir (1996) and Ferrante et al. (2001), animal behavior depends on the rearing environment, whereas Jones et al. (2000) and Van Borell \& Van Den Weghe (1999) reported that improvement in ambient conditions might result in benefits. The frequency of birds in the pasture area, i.e., bird behavior, might be affected by environmental factors. This indicates the importance of studies concerning the latter, which might affect not only the behavior but also animal welfare (Silva et al., 2003).

Shaded areas might be a solution to the management of ambient conditions in the semiintensive rearing system, since lower rates of permanence in the pasture might result from eventually high values of ambient variables. According to Bond et al. (1976), the existence of a shaded area might reduce in $30 \%$ or more the radiant thermal load (RTL) on the birds and such reduction depends on the cover material that is used to produce the shaded area.

Therefore, this study was carried out to evaluate the use of a black plastic screen (sombrite) as a means of minimizing the effects of temperature on the rates of bird permanence in the pasture, as well as to evaluate its influence on the behavior of permanence in the pasture during the hottest hours of the day.
Finally, the influence of this management on final bird performance was also evaluated.

\section{MATERIAL AND METHODS}

Four strains of broiler chickens were used: two experimental strains (Caipirinha and Carijó) that are being developed by the Departamento de Genética from ESALQ/USP and two commercial lines (Embrapa and Paraíso Pedrês).

One-day-old chicks were obtained from the experimental hatchery of the Departamento de Genética and were vaccinated against Marek's disease. The birds were distributed into 16 sex-mixed groups and housed in experimental pens measuring $4.5 \mathrm{~m}^{2}$ of inside area and an outside area of natural pasture measuring $35 \mathrm{~m}^{2}$. There were four pens per strain and 35 birds per pen. A black plastic screen (sombrite) was installed (50\%) in the pasture of two pens per strain at the height of the poultry house eaves. The maximum shaded area was $9 \mathrm{~m}^{2}$ measured from the eaves of the poultry house.

In the first week, heating was provided by one incandescent light per pen (150 Watts). Two initial drinkers and feeders were used per pen until seven days of age. Afterwards, water and feed were provided in adult automatic bell drinkers and tubular feeders (one per pen). Diets (Table 1) and water were provided ad libitum throughout the experimental period until 75 days of age. The birds were also vaccinated against Newcastle and Gumboro diseases in the drinking water at 7 and 21 days of age, according to the manufacturer's recommendations.

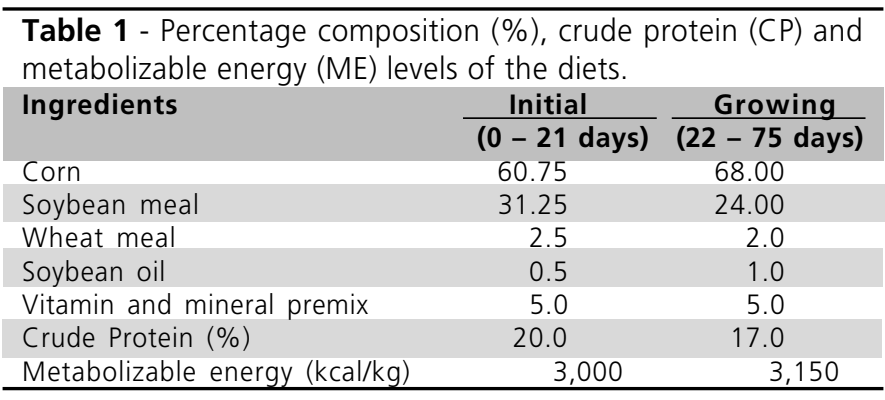

At 21 days of age, birds were allowed free access to the pasture of their pen. After 14 days of adaptation, the monitoring period started. From 35 to 75 days of age, data concerning the number of birds in the pasture area were collected from $8 \mathrm{~h}$ to $18 \mathrm{~h}$ at each two hours, in order to obtain the daily mean rate of permanence in the pasture. 
Barbosa Filho JAD, Silva MAN, Silva IJO, Coelho AAD, Savino VJM
Body weight was measured using a dynamometertype scale with $5 \mathrm{~kg}$ capacity and $20 \mathrm{~g}$ precision. Feed conversion ( $\mathrm{g}: \mathrm{g}$ ) was determined dividing feed intake by weight gain (per bird).

Temperature data of the black globe were recorded during the same period. These are indicative of the thermal sensation of the bird as a function of the environment, and are also indicative of the ambient temperature inside the poultry house, under the sombrite (shaded area) and in the pasture. Therefore, it was possible to compare the influence of the environment management on bird behavior during the hottest hours of the day and also on the improvement in thermal comfort (BGHI and enthalpy). Ambient indexes (BGHI and enthalpy) were calculated for each environment at each two hours (between 8:00 and 18:00).

A completely randomized experimental design was used to analyze data of body weight and feed conversion, according to a $4 \times 2$ factorial arrangement ( 4 strains and 2 rearing environments) with 2 repetitions. The rate of permanence in the pasture was evaluated during 40 consecutive days according to a randomized block design in a $4 \times 2 \times 6$ factorial (4 strains, 2 environments and 6 hours) with 2 repetitions per experimental unity. Ambient parameters (environmental temperature, globe temperature and relative humidity) within the poultry house and in the pasture (without sombrite and with sombrite) were also analyzed according to a $4 \times 2$ factorial arrangement (4 strains and 2 environments) and days were considered as blocks.

Analysis of variance of the evaluated parameters was performed using the General Linear Models procedure (GLM) of the statistical package SAS (2005). Differences between means were analyzed using the Tukey's test $(p<0.05)$.

\section{RESULTS AND DISCUSSION}

Table 2 presents feed conversion and body weight at 75 days of age, i.e., at the end of the monitoring period during which the rates of bird permanence in the pasture were evaluated.

There were no differences in feed conversion for the treatments with and without shading within strains (rows) or between strains (columns). On the other hand, there were significant differences in body weight between shaded and non-shaded pastures, indicating that the shaded area affects final body weight. Birds from Carijó and Embrapa strains showed no differences
Behavior and Performance of Broiler Strains Reared under Semi-Intensive System with Shaded Areas

in body weight, independent of treatment (with or without shaded area), whereas (aipirinha and Paraíso Pedrês strains showed the smallest and greatest body weights, respectively, both in shaded and non-shaded pastures.

\begin{tabular}{|c|c|c|c|c|}
\hline \multirow[t]{2}{*}{ Strain } & \multicolumn{2}{|c|}{ Body Weight } & \multicolumn{2}{|c|}{ Feed conversion } \\
\hline & Shaded & Non-shaded & Shaded & Non-shaded \\
\hline Caipirinha & $2,480 \mathrm{cA}$ & 2,308 cB & $2.85 \mathrm{aA}$ & $2.87 \mathrm{aA}$ \\
\hline Carijó & $2,930 \mathrm{bA}$ & $2,863 \mathrm{bB}$ & $2.90 \mathrm{aA}$ & $2.93 \mathrm{aA}$ \\
\hline Embrapa & $2,950 \mathrm{bA}$ & $2,820 \mathrm{bB}$ & $2.91 \mathrm{aA}$ & $2.97 \mathrm{aA}$ \\
\hline Paraíso Pedrês & 3,150 aA & $3,092 \mathrm{aB}$ & $3.00 \mathrm{aA}$ & $3.080 \mathrm{aA}$ \\
\hline & & & & $\begin{array}{l}\text { etters in the } \\
\text { Tukey's test } \\
=9.6 \text {. }\end{array}$ \\
\hline
\end{tabular}

Table 3 shows the mean permanence rates in the pasture of the four evaluated strains. Paraíso Pedrês showed lower mean permanence rate in the shaded pasture (5.7 birds/day) and also in the non-shaded pasture (5.3 birds/day) throughout the experimental period. These findings were statistically different from the results of the other strains (Table 3); Carijó showed the gretare mean of permanence rate ( 7.8 birds/day and 7.6 birds/day). Strains Carijó, Caipirinha and Embrapa were more adapted to the semi-intensive rearing system, corroborating previously reported results that also showed differences in the adaptation of broiler strains (Silva et al., 2003).

\footnotetext{
Table 3 - Mean rates of permanence in the pasture for each strain (birds/day) between 35 and 75 days of age according to the environment.
}

\begin{tabular}{lcc} 
Strain & \multicolumn{2}{c}{ Environment } \\
\cline { 2 - 3 } & Shaded & Non-shaded \\
Carijó & $7.8 \mathrm{Aa}$ & $7.6 \mathrm{Aa}$ \\
Caipirinha & $7.6 \mathrm{Aa}$ & $7.4 \mathrm{Aa}$ \\
Embrapa & $7.3 \mathrm{Aa}$ & $7.3 \mathrm{Aa}$ \\
Paraíso Pedrês & $5.7 \mathrm{Ba}$ & $5.3 \mathrm{Ba}$ \\
\hline
\end{tabular}

Means followed by different capital (small) letters in the same column (row) are statistically different by the Tukey's test $(p<0.05)$. C.V. $(\%)$ : Permanence rate $=8.1$.

Ambient temperature, dark globe temperature and relative humidity means are shown in Table 4 according to the three evaluated environments.

Mean ambient and dark globe temperatures in the shaded pasture were lower than the temperatures inside the poultry house or in the non-shaded pasture throughout the day (8:00 to 18:00 h). There were significant differences $(p<0.05)$ between the two environments in the hottest periods of the day $(10: 00$ to $16: 00 \mathrm{~h}$ ). 
Barbosa Filho JAD, Silva MAN, Silva IJO, Coelho AAD, Savino VJM
Behavior and Performance of Broiler Strains Reared under Semi-Intensive System with Shaded Areas

\begin{tabular}{|c|c|c|c|c|c|c|c|c|c|}
\hline \multirow[t]{2}{*}{ Hour } & \multicolumn{3}{|c|}{ Environmental Temp. } & \multicolumn{3}{|c|}{ Globe temperature } & \multicolumn{3}{|c|}{ Humidity } \\
\hline & NS & SP & $\mathrm{IH}$ & NS & $S P$ & TH & NS & SP & TH \\
\hline $8: 00$ & $20.25 \mathrm{Ba}$ & $19.00 \mathrm{Ba}$ & $26.67 \mathrm{Ba}$ & $20.25 \mathrm{Ca}$ & $19.00 \mathrm{Ba}$ & $20.87 \mathrm{Ca}$ & $99.75 \mathrm{Aa}$ & $83.00 \mathrm{Ab}$ & $90.00 \mathrm{Aab}$ \\
\hline 10:00 & $37.25 \mathrm{Aa}$ & $18.33 \mathrm{Bb}$ & $24.40 \mathrm{Bb}$ & $38.50 \mathrm{ABa}$ & $18.33 \mathrm{BC}$ & $25.10 \mathrm{Cc}$ & $40.00 \mathrm{Bb}$ & $86.66 \mathrm{Aa}$ & $77.37 \mathrm{ABa}$ \\
\hline $12: 00$ & $41.00 \mathrm{Aa}$ & $19.00 \mathrm{BC}$ & $28.60 \mathrm{Ab}$ & $45.25 \mathrm{ABa}$ & $19.00 \mathrm{BC}$ & $29.10 \mathrm{ABb}$ & $32.50 \mathrm{BC}$ & $84.33 \mathrm{Aa}$ & $64.95 \mathrm{BCb}$ \\
\hline $14: 00$ & $41.25 \mathrm{Aa}$ & $23.00 \mathrm{Bb}$ & $31.22 \mathrm{Ac}$ & $47.50 \mathrm{Aa}$ & $23.66 \mathrm{BC}$ & $32.50 \mathrm{Ab}$ & $26.50 \mathrm{Bb}$ & $64.66 \mathrm{ABa}$ & $50.82 \mathrm{Ca}$ \\
\hline $16: 00$ & $39.25 \mathrm{Aa}$ & $30.33 \mathrm{Aa}$ & $30.77 \mathrm{Aa}$ & $41.00 \mathrm{ABa}$ & $33.00 \mathrm{Ab}$ & $31.60 \mathrm{Ab}$ & $31.50 \mathrm{Ba}$ & $41.33 \mathrm{Ba}$ & $48.77 \mathrm{Ca}$ \\
\hline $18: 00$ & $36.00 \mathrm{Aa}$ & $31.33 \mathrm{Aa}$ & $30.80 \mathrm{Aa}$ & $36.25 \mathrm{Ba}$ & $33.33 \mathrm{Aa}$ & $32.55 \mathrm{Aa}$ & $32.50 \mathrm{Ba}$ & $40.00 \mathrm{Ba}$ & $47.42 \mathrm{Ca}$ \\
\hline
\end{tabular}

'NS - Non-shaded pasture, SP - Shaded pasture, and IH - Inside the poultry house.Means followed by different capital (small) letters in the same column (row) are statistically different by the Tukey's test $(p<0.05)$. C.V $(\%)$ : Environmental temperature $=6.7$; Globe temperature $=6.1$; Humidity $=7.3$

Relative humidity was smaller in the non-shaded pasture and there was also significant differences $(p<0.05)$ in the hottest periods of the day. This might be explained by the fact that the presence of a cover reduces humidity dissipation in the physical environment.

The environment parameters changed throughout the monitoring period, and there was a significant difference $(p<0.05)$ between the three evaluated environments within each evaluation time.

Table 5 shows the comfort indexes (enthalpy and $\mathrm{BGHI}$ ) of the shaded and non-shaded pastures and inside the poultry house.

According to Curtis (1983), BGHI values similar or higher than 76 decrease the productive performance of the birds, and constitute one of the most important problems in modern broiler production.

After 10:00, lower BGHI and enthalpy values were seen in the shaded pasture (Table 5), and consequently, the best thermal comfort conditions, whereas the worst conditions were seen in the nonshaded pasture.

The means of daily variation in the permanence rates according to the period of monitoring throughout the day and to the environment are shown in Table 6.

There were significant differences $(p<0.05)$ in the mean rates of permanence in the pasture between strains in the hottest periods of the day, compared to the other monitoring periods.

\begin{tabular}{lcccc}
\hline Table 5 - Thermal comfort index in the three environments & '. \\
Time & Comfort Index * & Non-shaded & Shaded & House \\
8:00 & Enthalpy & 61.5 & 51.5 & 61.1 \\
& BGHI & 68.0 & 66.0 & 69.0 \\
10:00 & Enthalpy & 82.7 & 50.0 & 65.3 \\
& BGHI & 87.0 & 65.0 & 73.0 \\
$12: 00$ & Enthalpy & 87.9 & 51.9 & 76.2 \\
& BGHI & 89.0 & 66.0 & 78.0 \\
$14: 00$ & Enthalpy & 79.2 & 55.6 & 72.4 \\
& BGHI & 95.0 & 71.0 & 81.0 \\
$16: 00$ & Enthalpy & 79.7 & 61.3 & 70.8 \\
& BGHI & 92.0 & 80.0 & 80.0 \\
$18: 00$ & Enthalpy & 71.5 & 63.4 & 61.9 \\
& BGHI & 85.0 & 77.0 & 80.0 \\
\hline
\end{tabular}

Enthalpy - kJ / kg dry air. BGHI - Black globe humidity index.

It might be observed that, during the hottest hours, the strains tended to show greater permanence rate in the shaded pasture; the greatest mean rate of permanence in this period was seen for the Carijó strain. It is worth noting that the birds tended to stay out of the shaded areas at the end of the day (18:00).

\section{CONCLUSION}

The use of a black plastic screen (sombrite) to provide shading of the pasture in the semi-intensive rearing system improved the ambient conditions, welfare and performance of the birds, based on thermal comfort and final bird weight. The behavior of each strain was positively affected, since the rate of

\begin{tabular}{|c|c|c|c|c|c|c|c|}
\hline Strain & Time & 8:00 & $10: 00$ & $12: 00$ & $14: 00$ & $16: 00$ & $18: 00$ \\
\hline & Environment & & & & & & \\
\hline \multirow[t]{2}{*}{ Caipirinha } & Shaded & $13.57 \mathrm{Aa}$ & 14.28 Aa & $3.14 \mathrm{Ab}$ & $0.42 \mathrm{Ab}$ & $1.42 \mathrm{Ab}$ & $12.85 \mathrm{Aa}$ \\
\hline & Non-shaded & $16.42 \mathrm{Aa}$ & $13.28 \mathrm{Aa}$ & $0.14 \mathrm{Bb}$ & $0.57 \mathrm{Ab}$ & $0.14 \mathrm{Bb}$ & $13.57 \mathrm{Aa}$ \\
\hline \multirow{2}{*}{ Carijó } & Shaded & $16.00 \mathrm{Aa}$ & $11.85 \mathrm{Aa}$ & $3.28 \mathrm{Ab}$ & $2.14 \mathrm{Ab}$ & $0.71 \mathrm{Bb}$ & $13.00 \mathrm{Ba}$ \\
\hline & Non-shaded & $10.85 \mathrm{Bb}$ & $11.00 \mathrm{Ab}$ & $2.28 \mathrm{Ac}$ & $0.85 \mathrm{BC}$ & $3.71 \mathrm{Ac}$ & $18.28 \mathrm{Aa}$ \\
\hline \multirow[t]{2}{*}{ Embrapa } & Shaded & $20.28 \mathrm{Aa}$ & $8.30 \mathrm{Ac}$ & 1.14 Ad & $0.57 \mathrm{Ad}$ & $0.85 \mathrm{Bd}$ & $12.42 \mathrm{Bb}$ \\
\hline & Non-shaded & $13.00 \mathrm{Bb}$ & $8.70 \mathrm{Ac}$ & $1.85 \mathrm{Ad}$ & $0.28 \mathrm{Ad}$ & $3.42 \mathrm{Ad}$ & $16.71 \mathrm{Aa}$ \\
\hline \multirow[t]{2}{*}{ Paraíso Pedrês } & Shaded & $16.00 \mathrm{Aa}$ & $9.57 \mathrm{Ab}$ & $0.15 \mathrm{BC}$ & $0.14 \mathrm{Ac}$ & $1.00 \mathrm{BC}$ & $7.42 \mathrm{Bb}$ \\
\hline & Non-shaded & $6.14 \mathrm{Bb}$ & $3.85 \mathrm{Bbc}$ & $1.42 \mathrm{Acd}$ & $0.14 \mathrm{Ad}$ & $2.71 \mathrm{Acd}$ & $17.57 \mathrm{Aa}$ \\
\hline
\end{tabular}

Means followed by different capital letters (between environments within the same strain) or different small letters (between times within the same environment) are different by the Tukey's test $(p<0.05)$. Coefficient of variation $(\%)$ : birds/hour $=9.4$. 
Barbosa Filho JAD, Silva MAN, Silva IJO, Coelho AAD, Savino VJM

bird permanence in the pasture increased when this was shaded, so that the strains Caipirinha, Carijó and Embrapa were considered to be more adapted to the semi-intensive rearing system.

\section{REFERENCES}

Bockisch FJ, Jungbluth T, Rudovsky A. Technical indicators for evaluation of housing systems for cattle, pigs and laying hens relating to animal welfare. Zuchtungskunde 1999; 71(1):38-63.

Bond TE, Neubauer LW, Givens RL. The influence of slope and orientation on effectiveness of livestock shades. Transaction of the ASAE 1976; 19(11):134-136.

Craig JV, Muir WM. Group selection for adaptation to multiplehen cages: behaviour responses. Poultry Science 1996; 75(10):11451155.

Curtis SE. Environmental management in animal agriculture. Ames: The lowa State University Press; 1983.

Ferrante V, Verga M, Mangiagalli MG, Carenzi C. Behaviour reactions, semen quality and testosterone levels in cocks: genetic implications. Animal Welfare 2001; 10(3):269-279.

Furlan RL, Macari M, Moraes VMB, Malheiros RD, Malheiros EB, Secato ER. Alterações hematológicas e gasométricas em diferentes linhagens de frangos de corte submetidos ao estresse calórico agudo. Revista Brasileira de Ciência Avícola 1999; 1(1):77-84.

Jones RB, Carmichael NL, Rayner E. Pecking preferences and predispositions in domestic chicks: implications for the development of environmental enrichment devices. Applied Animal Behaviour Science 2000; 69(4):291-213.

Macari M, Furlan RL. Ambiência na produção de aves em clima tropical. In: Silva IJO, editor. Ambiência na produção de aves em clima tropical. Piracicaba (SP): Degaspari; 2001. p.31-87.

SAS Institute Inc., SAS OnlineDoc ${ }^{\circledR}$. Disponível em: <http:// www.id.unizh.ch/software/unix/ statmath/sas/sasdoc/stat/ index.htm>. Acesso em: 04 ago. 2005.

Silva MAN. Seleção de linhagens de galinhas para corte adaptadas ao sistema de criação semi-intensivo [dissertação]. Piracicaba (SP): Universidade de São Paulo; 2001.

Silva IJO. Ambiência na produção de aves em clima tropical. Piracicaba (SP): Degaspari; 2001.

Silva RDM, Nakano M. Sistema caipira de criação de galinhas. Piracicaba (SP): O Editor: 1998.

Silva MAN, Rosário MF, Hellmeister Filho P, Coelho AAD, Savino VJM, Silva IJO, Menten JFM. Influência do sistema de criação sobre o desempenho, a condição fisiológica e o comportamento de linhagens de frangos para corte. Revista Brasileira de Zootecnia 2003; 32(1):208-213.
Behavior and Performance of Broiler Strains Reared under Semi-Intensive System with Shaded Areas

Sundrum A. Organic livestock farming - a critical review. Livestock Production Science 2001; 67(3):207-215.

Teixeira VH. Estudo dos índices de conforto em duas instalações de frango de corte para as regiões de Viçosa e Visconde do Rio Branco [dissertação]. Viçosa (MG): Universidade Federal de Viçosa; 1983.

Von Borell E, Van Den Weghe S. Development of criteria for the assessment of housing systems for cattle, pigs and laying hens relating to animal welfare and environmental impact. Zuchtungskunde 1999; 71(1):8-16. 


\section{Novidade!}

Livro

\section{MANEJO DE MATRIZES DE CORTE \\ $2^{\mathrm{a}}$ Edição}

Editores:

Marcos Macari

Ariel Antônio Mendes

Mais uma realização

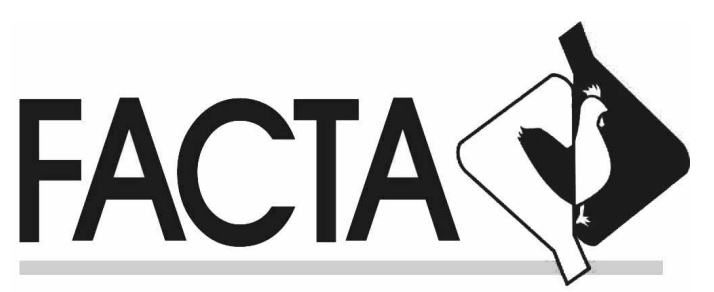

FUNDAÇÃO APINCO DE CIÊNCIA

E TECNOLOGIA AVÍCOLAS 